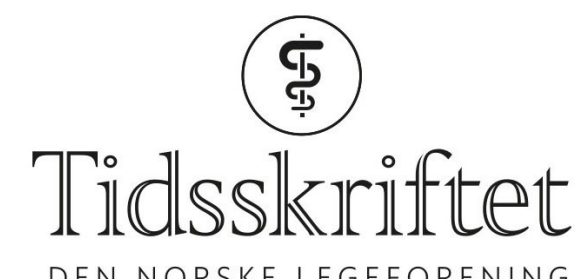

DEN NORSKE LEGEFORENING

\title{
Kjell A. Grøttum
}

MINNEORD

\section{OLE RYSSTAD}

PÅL FRIIS

BØRRE KÅSS

FRODE GALLEFOSS

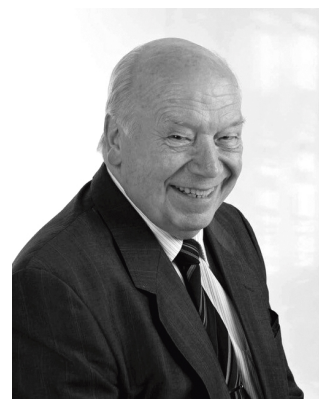

Tidligere avdelingsoverlege ved Sørlandet sykehus i Kristiansand, Kjell A. Grøttum, er død. Han ble født i 1934 og tok medisinsk embetseksamen ved Universitetet i Oslo i 1961. Etter få år begynte han å arbeide som ung lege på Rikshospitalet. Han kom inn i forskningsmiljøet rundt professor Peter F. Hjort, men det var kliniker, underviser og organisator han ville være.

I 1975 flyttet han til Tromsø for å bidra til etableringen av det nye medisinstudiet der. De av oss som traff Kjell under medisinstudiet, møtte en energisk og inspirerende lege og lærer. Han formidlet til oss verdier som var rotfestet $\mathrm{i}$ ham. Alle skulle lyttes til, tas på alvor og hjelpes, uansett stand i samfunnet. Alle hadde rett til lik hjelp uansett hvor en bodde i landet. Kjell tålte ikke antydning til nedsettende omtale av noen.

I 1984 begynte han å arbeide i Kristiansand. Arbeidskraften og arbeidslysten var høyere enn noensinne. Kjell reorganiserte medisinsk avdeling med voldsom kraft. Han fremhevet at legers læring måtte være livslang og la vekt på systematisk undervisning for alle. Han så viktigheten av at alle i en sykehusavdeling, uansett yrkesgruppe, må jobbe i lag og verdsettes for å oppnå resultater. Kjell stimulerte yngre kolleger til forskning og var begeistret når de kom med forslag til prosjekter. Han støttet helhjertet opp om det som var fornuftig. Han ledet i en periode spesialitetskomiteen i Legeforeningen og ble oppnevnt i en rekke råd og utvalg for Helsedepartementet og Helsedirektoratet.

Kjell tok initiativet til å etablere nevrologisk avdeling med slagenhet og akuttgeriatri i 
medisinsk avdeling. Seint på 8o-tallet snakket han om at store deler av pasientbehandlingen i fremtiden ville skje på poliklinikker og ikke ved innleggelse. Han fikk rett.

Han var frustrert over at kreftpasienter fra Sørlandet måtte reise til Oslo for å få strålebehandling og annen avansert kreftbehandling. Derfor tok han initiativ til å etablere Senter for kreftbehandling i Kristiansand. Han møtte motstand mot ideen i Oslo, men takket være en klok strategi, hardt arbeid og utholdenhet åpnet senteret i 2001. Tusenvis av pasienter kan takke Kjell for at de har kunnet få tiltrengt kreftbehandling lokalt. Kjell var rotfestet i gamle sosialdemokratiske verdier fra etterkrigstiden. Samfunnsoppgavene var viktige og skulle løses.

På Sørlandet står Kjell Grøttum som en av de største sykehusbyggere. Vi takker for tydelig lederskap og for godt vennskap.

Publisert: 24. juni 2019. Tidsskr Nor Legeforen. DOI: 10.4045/tidsskr.19.0344

(C) Tidsskrift for Den norske legeforening 2020. Lastet ned fra tidsskriftet.no 